\title{
Co-Working Couples and the Similar Jobs of Dual-Earner Households
}

\author{
by
}

\author{
Henry R. Hyatt \\ U.S. Census Bureau
}

CES 15-23 September, 2015

The research program of the Center for Economic Studies (CES) produces a wide range of economic analyses to improve the statistical programs of the U.S. Census Bureau. Many of these analyses take the form of CES research papers. The papers have not undergone the review accorded Census Bureau publications and no endorsement should be inferred. Any opinions and conclusions expressed herein are those of the author(s) and do not necessarily represent the views of the U.S. Census Bureau. All results have been reviewed to ensure that no confidential information is disclosed. Republication in whole or part must be cleared with the authors.

To obtain information about the series, see www.census.gov/ces or contact Fariha Kamal, Editor, Discussion Papers, U.S. Census Bureau, Center for Economic Studies 2K132B, 4600 Silver Hill Road, Washington, DC 20233, CES.Papers.List@census.gov. 


\begin{abstract}
Although a growing number of studies consider married or cohabiting couples as current, former or potential co-workers, there is surprisingly little evidence on the extent to which couples work at the same or at similar workplaces. This study provides benchmark estimates on the frequency with which married and cohabiting opposite-sex couples in the United States share the same occupation, industry, work location, and employer using Census 2000 data as well as administrative records. This study contains the first representative estimate of the fraction of couples that share an employer, which is in the range of $11 \%$ to $13 \%$. Shared employers account for most of the similarity between employer characteristics measured at fine levels of industry and location, but less than half of detailed occupational agreement. Longitudinal data on employment and residence of co-working couples indicates that the couples are much more persistent over time than the co-working relationship: ten times as many couples or more move into and out of co-working status, compared to those couples who continue to share an employer but whose co-residency begins or ends.
\end{abstract}

JEL Classification: J12, J21, J22

* Center for Economic Studies, U.S. Census Bureau. Contact: henry.r.hyatt@census.gov. Any opinions and conclusions expressed herein are those of the author(s) and do not necessarily represent the views of the U.S. Census Bureau. All results have been reviewed to ensure that no confidential data are disclosed. 


\section{Introduction}

Surprisingly little is known about the extent to which married or cohabiting couples share an employer, or, more broadly, maintain similar employment. It is well known that members of couples may share certain characteristics such as educational attainment or socioeconomic status: see Lam (1988), Kalmijn (1998), etc. on assortative mating and marital homogamy. Some studies have explored mechanisms through which similar employment or shared employers may arise, for example, it has also been established that many couples meet at work. ${ }^{1}$ A few studies have even explored the benefits of couples co-working, for example, Moen and Sweet (2002, 2004), Janning (2006) and Halbesleben (2010), although the frequency of the co-working couples was not of primary interest in these studies.

I provide evidence on the frequency with which couples work at the same or at similar workplaces in this study. I use microdata from the Census 2000 as well as administrative records to provide evidence on the frequency with which dual-earner couples work in similar industries, occupations, and locations, as well as the extent to which they share an employer. I show that similar employment is pervasive among U.S. dual-earner couples, and that $11 \%$ to $13 \%$ work for the same employer. I also provide evidence on how co-working couples arise, and find that established couples choosing to work at the same employer accounts for much more of this population than couples forming at work.

\footnotetext{
${ }^{1}$ For example, Bozon and Heran (1989) and Kalmijn and Flap (2001) provide evidence from retrospective surveys that asked couples how they met, including whether they met at work. McKinnish (2007) and Svarer (2007) estimate the relationship between workplace or occupational sex ratios (respectively) and divorce and marriage
} 
The degree to which dual-earner couples share employment characteristics, and especially, the same employer, matters for the role of marriage in the generation or mitigation of labor income risk. If dual-earner couples frequently share an employer, then the employer's success or failure will naturally result in similar positive or negative employment outcomes. Research by Hyslop (2001), Shore and Sinai (2010), Shore (2010, 2013), and Ostrovsky (2012) has shown that couples' incomes tend to move up or down together, despite the fact of the second potential earner as a source of insurance as in Lundberg (1985), Hess (2004), and Zhang (2011). As more than $10 \%$ of dual-earner couples are shown to share an employer in this study, co-working dual-earner couples likely account for a substantial portion of this positive comovement. Previous work has relied on shared observable characteristics generally available in publicly available datasets, industry and occupation, to explain co-movements in couple’s labor income. However, the fact that many or most couples who share the same industry or occupation also share the same employer suggest that these previously identified sources of labor income volatility may be accounted for by the extra labor income risk of sharing an employer.

Quantifying the extent to which couples share similar employment characteristics or the same employer is an outstanding issue for research. A thorough search of studies on dual-earner households yielded only a handful that contain reliable estimates of the frequency with which certain types of couples maintain similar employment, all of which are from studies in which that frequency is not of central interest. For characteristics such as industry, occupation, and very broad geography, it is possible to use a variety of public-use data sources to permit tabulations of the frequency with which couples share these employment characteristics. For example, Shore 
and Siani (2010) provide several straightforward tabulations of the frequencies which married couples share a highly specific industry or occupation.

There has been far less data available to consider the frequency with which couples share the same employer. Tabulations of the frequency with which couples share an employer have been done exclusively from nonrepresentative sources. Using surveys that take a small number of employers as a sample frame, Batt and Valcour (2003) and Moen and Sweet (2002, 2004) consider samples in which 15\% (from several employers), 40\% (from five manufacturing or utilities employers) and 17\% (from two universities) of dual-earner married couples work for the same employer, respectively. This previous evidence indicates that a substantial fraction of couples work for the same employer or otherwise engage in similar employment, but it does not pin down its extent. The frequency of shared employers reported here is slightly less than the low end of this range, at $11 \%$ to $13 \%$.

The primary purpose of this study is to provide reliable, comprehensive estimates of the frequency with which members of a dual-earner opposite-sex couple work in similar jobs: defined according to occupation, industry, location, and employer. These estimates are obtained from a unique set of linked datasets. The frame of this analysis is the long form of the Census 2000, a one-in-six sample of the population of the United States. Public-use Census 2000 data are used whenever possible to measure the extent to which couples work in similar self-reported occupations, industries and locations. A $1 \%$ sample is used to calculate statistics that cannot be calculated directly from the public-use microdata. Administrative records on the universe of Unemployment Insurance taxable employment maintained by the U.S. Census Bureau's 
Longitudinal Employer-Household Dynamics (LEHD) program permits estimates of the extent to which couples share an employer, as well as alternative estimates of the extent to which couples work in similar industries and locations (administrative records on occupation are not available). These linked administrative records are used for additional tabulations of the $1 \%$ sample of Census 2000 long form respondents.

The findings are as follows for (pooled) married and cohabiting couples in which both members are age 16 to 64 in the year 2000. Occupation is only measured in the Census 2000 (not in the administrative records): $4 \%$ of couples work in the same Census occupation, and $13 \%$ share occupations that crosswalk to the same SOC Major Group. There is somewhat more industry agreement, as measured both in the Census 2000 and administrative records. In the Census 2000, 12\% work in the same narrow Census industry and 21\% work in the same broad industry, as defined at the NAICS supersector level, while in the administrative records, $13 \%$ to $15 \%$ work at the same narrow industry defined at the 6-digit NAICS level, and $25 \%$ to $26 \%$ work in the same NAICS supersector.

Not surprisingly, since couples generally share a residence, there is also substantial similarity in the locations where couples work. In the Census 2000, $10 \%$ of dual-earner households work in the same Census block, $68 \%$ work in the same county, and tabulation of the underlying microdata indicates that $82 \%$ work within 25 miles of each other. In the administrative records, a comparable number, $11 \%$ to $13 \%$, work in the same Census block, while only $50 \%$ work in the same county and $66 \%$ within 25 miles of each other. Administrative records sources consistently suggest that couples work at greater distances from each other, 
which is in part due to the difference between the reported place of a business establishment and the location where the person works, and in part due to uncertainty regarding the establishment of employment for workers at multi-establishment employers.

This paper also contains what is perhaps the first comprehensive estimate of the frequency with which couples share an employer. The linked data indicate that $10 \%$ to $12 \%$ of couples work at the same establishment and $11 \%$ to $13 \%$ work for the same firm. This sharing of an employer accounts for much of the shared employment in the Census 2000 responses: of those who work in the same narrow Census industry, about 63\% work in the same workplace. $70 \%$ of those who work in the same Census block (narrowly-defined geography) work for the same employer. About $47 \%$ of those who report working in the same narrow occupation share an employer. 83\% of those who report the same Census occupation and Census industry work at the same workplace. While about half or more of shared detailed responses are due to sharing an employer, at broader levels, sharing of job characteristics at broader definitional levels is associated with less frequent sharing of an employer.

The longitudinal results can also inform the discussion of the extent to which the workplace serves as a mechanism for household formation. By distinguishing between couples that were or were not co-working or co-resident prior in the years 1999 and 2001, it is possible to obtain an estimate of how frequently co-working couples choose the same employer relative to those who meet at work, suggesting a strong role for married and unmarried partner couples as a source of job referrals. Of new co-working couples, ten times as many couples existed prior to the shared employment than were previous co-workers who were previously co-resident. This 
implies that, for the vast majority of couples, they chose the same employer after meeting, rather than meeting on the job.

\section{Similar Employment in the Census 2000 Long Form}

The long form of the Census 2000, which one in six respondents to the Census 2000 received, asked about employment. Respondents provided information on at most one employer, including the employer's industry and location, as well as the respondent's occupation. Tabulations in this paper come either from the Census 2000 long form public-use microdata, or else records from a $1 \%$ random sample from the underlying microdata, and tabulate the responses of the roughly 8.5 million opposite-sex married and unmarried partner households sampled in the long form and who do not live in group quarters. All results in the body of this paper are for the $83 \%$ of couples where both members are age $16-64$, and pool the $90 \%$ of couples who are married with the remainder of cohabiting couples (unless noted otherwise). Furthermore, efforts are made whenever practical to present estimates that are representative of this so-defined working-age population of couples who live in the 50 states and the District of Columbia. $^{2}$

\footnotetext{
${ }^{2}$ Note that as the empirical results presented in this paper were prepared, a substantial amount of attention was devoted to the missing data issues that arose in each stage of estimation. For example, the Census 2000 microdata file has a substantial amount of missing sub-county work location information. There are also a variety of issues involved in the use of administrative data, including the reliability of person identification, the completeness of residency information, the exact establishment of employment for those whose Unemployment Insurance accounts cover multiple worksites, and coverage issues involved in construction national estimates from a partial (thirty-eight
} 
Several additional variables not directly available in the source dataset are defined. The distance between places of work compares the latitude and longitude of Census block centroids. Note that this implies that two workplaces in the same block will have distance zero from each other. $^{3}$ A U.S. Census Bureau (2001a) crosswalk aggregates Census 2000 industries to 1997 NAICS Sectors and Supersectors. A similar U.S. Census Bureau (2001b) crosswalk is used to aggregate Census 2000 occupations to 2000 SOC Minor Groups and Major Groups. All elements of the dataset have county of work, but in $17 \%$ of households at least one member lacks subcounty place of work information due to answers that are incomplete or are otherwise difficult to geocode. Imputation is used to fill missing common location and distance between worksites information conditional on observable characteristics. For the results obtained from this $1 \%$ subset, households are weighted by the person weight of the primary respondent, times 100 .

The employment rates for the sample of Census 2000 long form respondents where both members are age 16-64 are in Table 1 . About 58\% of these working-age couples in the U.S. in the year 2000 are dual-earner, while most of the remainder are couples where only the male works. Unmarried partner households have higher female employment rates, lower male employment rates and are two to three percentage points more likely to be dual-earner, relative to

state) set of datasets, and in certain cases the results from different tabulation strategies are compared, to provide better understanding of the robustness of the overall findings.

${ }^{3}$ The distance between places of work is measured using block centroids when using self-reported place of work from the Census long form; later in the paper when the LEHD administrative data is used, the distance between geocoded employer addresses rather than block centroids. 
married couples. Among working age couples, having neither partner employed is relatively infrequent, and occurs in less than $10 \%$ of married or cohabiting couples.

The Census 2000 long form indicates that couples exhibit substantial similarity in their employment characteristics. The frequency of shared employment characteristics for dual-earner couples is in Table 2. The geographic agreement of their employment is quite substantial: $10 \%$ of dual-earner couples work in the same Census block and $68 \%$ in the same county. In $0.7 \%$ of dual-earner couples, both members work from home, so these couples account for less than $10 \%$ of all who work in the same Census block. 38\% of dual-earner couples work within five miles of each other, about $76 \%$ work within 25 miles of each other. Industry agreement is also quite substantial: among dual-earner couples, $12 \%$ work for the same Census industry, and $22 \%$ of couples report responses that crosswalk to the same NAICS supersector. Rather less agreement is found in occupation: only $4 \%$ of dual-earner couples work in the same Census occupation, and only $13 \%$ of respondent occupations crosswalk to the same SOC Major Group level. Overall, the outcomes of married and cohabiting couples are sufficiently similar that, to limit the number of tables, subsequent results will pool married and cohabiting couples unless otherwise noted.

Table 3 presents the occupation distribution, by SOC major group, for males and females in dual-earner couples along with the subpopulation of couples that share a Census occupation and those who report occupations that crosswalk to the same SOC major group. The occupation distribution of those couples who share an occupation is broadly similar to the occupation distribution of members of dual-earner couples. Those occupations that are skewed toward one sex tend to have fewer same-occupation couples, especially Construction and Extraction, and 
Installation, Maintenance, and Repair. However, there are certain exceptions. Education, Training and Library occupations are predominantly female and have a large share of dual-earner couples. Interestingly, this is because for males employed in an occupation in this SOC Major Group and are in a dual-earner couple, 35\% have a partner in the same narrow Census occupation, and $68 \%$ have a partner whose occupation is in the same SOC Major Group. In other words, men in education tend especially to marry in education.

A similar story appears in Table 4, which presents Census 2000 responses by the NAICS supersector of employment where both industry and employment agree, as well as the industry share among all dual-earner couples. It is very common for couples who share an industry to work in Manufacturing, as well as Education Services, and is also more frequent than the broader share of employment would otherwise suggest. Health Care and Social Assistance, along with Retail Trade, have a large share of shared industry couples, which largely reflects their employment shares. The predominantly male Construction industry has proportionately few couples with it as a shared industry.

In order to address the question of which couples are more likely to work at the same workplace, additional demographic breakdowns are presented in Table 5 for all couples as well as those who share a Census industry, occupation or block. Couples who share a Census block are disproportionately older (age 55-64), while those who share an industry tend to be younger (16-24 and 24-44). Those who share an occupation or block are more likely to be Asian or Hispanic, while those who share an industry are more likely to be Black or Hispanic. Those who share an occupation are more highly educated, those who share an industry are less educated, and 
those who share a Census block are somewhat more likely to have less than a high school diploma.

Households naturally share the same local labor market, and this naturally accounts for some of a couple's shared employment characteristics. For example, if there is a single dominant employer in the area in which the household lives (e.g., a "factory town"), the respondents will naturally be more likely to report working in the same industry or geography, but not in a way that is different from agreement that they would share with others in the same area. To address this question, Table 6 includes estimates where the shared workplace characteristics are defined for the actual couples themselves, and also for simulated couples in which partners are selected at random from the same Census block. ${ }^{4}$ Only about a third of respondents have a potential alternative partner from the same Census block, so a "Truth" column is provided to present the characteristics of this so-defined subset. Narrowly defined characteristics are generally an order of magnitude lower in the randomly selected partners than in the true data. Of the $10.8 \%$ of those who share the same Census block, less than $10 \%$ of those (0.8\%) share the same Census block as their randomly selected partner. Other more broadly defined industry and occupation are about half as common in the randomly selected partners than in the actual partners. This comparison is useful because it suggests that the fact of the household is a much stronger predictor of employment outcomes than similar geography alone, as established by such studies as Bayer, Ross, and Topa (2008), Hellerstein, Kutzbach, and Neumark (2013), and Schmutte (2015).

\footnotetext{
${ }^{4}$ These estimates do not include observations where there is imputed geography of work.
} 
In addition to experiencing the same local labor market, people with similar characteristics tend to marry each other, and this positive assortative mating may additionally account for shared employment characteristics. Additional estimates where in addition to selecting someone from the same Census block, the potential match requires similar demographic characteristics are also included in Table 6. There is noticeably more agreement in the randomly selected partners in this so-defined subset, consistent with this line of reasoning. Compared to the matches that do not condition on demographic characteristics, shared narrow Census occupation, Census industry, and Census block all jump by roughly half, while the baselines for comparisons show little change. For the shared combinations of narrow Census industry and Census block, the randomly selected matches double for those random matches that condition on the Census block and demographics, compared to random matches that condition on Census block only. But despite these gains, all such shared narrow characteristics are still at least $75 \%$ lower in the randomly selected groups than the baseline, suggesting that being part of the same household plays is quite predictive of sharing highly specific employment characteristics.

Overall, above results agree substantially with the shared industry and occupation tabulations presented by Shore and Sinai (2010), who consider responses from the Survey of Income and Program Participation 1996-2000 and the 1980, 1990, and 2000 Censuses. ${ }^{5}$ The $12 \%$ of Census 2000 responses working in the same industry is between the estimates presented

\footnotetext{
${ }^{5}$ There are some definitional differences of note. Shore and Sinai (2010) report industry and occupation according to the 1950 Census categories (rather than the 2000 Census categories used in this paper) and have several rules for eliminating observations from their samples, including that both members must be age 25 or older.
} 
by Shore and Sinai (2010): higher than the 9\% they calculate using the Survey of Income and Program Participation but less than the $15 \%$ using the three Censuses. The $4 \%$ working in the same Census occupation is close to the 3\% Shore and Sinai (2010) report for the Survey of Income and Program Participation, but substantially less than the 10\% they report using the three Censuses.

\section{Same and Similar Workplaces in Employer-Household Data}

This section provides new evidence on the frequency with which dual-earner couples work at the same or similar employers in the year 2000 using the above described household data from the Census 2000 linked to administrative employment records from the Longitudinal Employer-Household Dynamics (LEHD) program. Employment records in this snapshot include those of the private sector and by state and local governments, and so exclude military service, federal government employment, and the self- employed. While in the Census 2000, respondents report only on the job at which they worked the most in the last week, the administrative records sources contain information from multiple employers when present. For additional comparability with the Census 2000, as well as to avoid timing issues when asserting that a couple has similar employment, I consider employment for employees whose employers report wage records for them in the first and the second quarter of the year 2000, which indicates that the individual had an ongoing employment relationship at the start of the quarter, that is, the end of March in the

year 2000. This selection is done for more director comparison with the Census 2000, which targets March $30^{\text {th }}$, 2000 as its response date. 
These estimates are derived from thirty-eight state-specific administrative datasets containing Unemployment Insurance wage reports and establishment-level workplace characteristics. Unemployment Insurance tax records provide person-specific employment at the Unemployment Insurance account (called the State Employer Identification Number, or SEIN) level and are linked with Census 2000 respondents at the person level. The workplace characteristic files provide information on industry and geography and the (federal) Employer Identification Number (EIN), which is then linked to the Longitudinal Business Database to aggregate of EINs to the firm (shared operational control) level, see Jarmin and Miranda (2002). The integration of these data into the LEHD universe is described in Haltiwanger et al. (2014). ${ }^{6}$

Three stages of imputation complete the information on industry, work location and employer for the universe of Census 2000 responses, which are conducted as follows. First, Unemployment Insurance accounts with multiple establishments, which is about half of all employment, the establishment of employment is assigned by imputation. ${ }^{7}$ Next, because there

\footnotetext{
${ }^{6}$ For additional details about the LEHD data, see Abowd et al. (2009) and McKinney and Vilhuber (2011).

${ }^{7}$ The workplace allocations in the standard Unit-to-Worker file used in many studies that employ LEHD microdata are not used in the main analysis because the imputation assignments allocate members of couples to establishments independently of each other, and this naturally results in a lower estimate of the share of couples who work at the same establishment. For the couples who live in "in scope” states, and who are both in the LEHD data, $8.9 \%$ work in the same Census block, $8.2 \%$ work at the same establishment, and only $36 \%$ work in the same county. Note that this imputation means that the estimates of shared workplace and similar work location will be sensitive to the imputation method. Industry will also be sensitive to the workplace assignment methodology, but most multi-unit employers have a similar industry, especially at the sector or supersector level. Estimates of shared employers at the
} 
are only thirty-eight ${ }^{8}$ states that have provided data for the year 2000, county-level information is imputed for missing states. This process imputes an employment outcome for each household for each county: male only works, female only works, both works, and neither works, and, if both work in the county, a stage of imputation assigns whether they share a workplace, and, if not, what characteristics their establishments of work share, if any. This stage then compares all counties where the couples work and assigns shared firm or industry characteristics. Finally, those couples in which one or both members lack a person identifier have imputed employment outcomes. When applicable, the missing geography and missing person identifiers utilize Census 2000 responses to predict shared employment outcomes.

Because the LEHD data for the year 2000 are for a 38-state sample, and also exclude federal workers and the self-employed, the results in Tables 7 and 8 contain estimates from a several different methodologies. "All Couples" refers to all couples in the $1 \%$ sample of Census 2000 households. Of these, those that in the "38 States" column are those that are in the 38-state set of LEHD states in the year 2000. The column labeled "All Couples" and "38 States" is, therefore, the direct tabulation from tabulating the Census 2000-LEHD matches. The "National" analogue is completed via imputation. The columns that are calculated "Excluding Census 2000 Feds, Self-Employed" exclude couples where either member reported their dominant

level of the Unemployment Insurance account (SEIN) or broader (EIN and firm) are by construction unaffected by establishment imputation by construction: an establishment is always associated with one single SEIN.

${ }^{8}$ Specifically, AK, CA, CO, FL, GA, HI, ID, IL, IN, KS, LA, MD, ME, MI, MN, MO, MT, NC, ND, NE, NJ, NM, NV, NY, OH, OR, PA, RI, SC, SD, TN, TX, UT, VA, VT, WA, WI, and WV. 
employment as federal or self-employed in the Census 2000, and so it would not be expected for the LEHD data to contain information on their primary employer. Of those, the "38 States" are calculated on the 38-state subset, and the "National" estimate includes those imputed work information for employment outside those 38 states.

The frequency with which members of opposite-sex couples work in the LEHD data is shown in Table 7 for these alternative definitions. 39\% to 52\% of couples have both members working at an employer whose workers are covered by Unemployment Insurance at the end of March in the year 2000. The significant range of estimates comes about because labor market attachment rates are naturally higher when the administrative data are corrected for the known coverage issue, that federal employees and the self-employed do not appear in the LEHD data. But even the high end of this range is lower than the Census 2000 responses of employment in the year 2000 , which indicate that $57 \%$ to $58 \%$ are dual-earner. Of the remainder, about half are couples in which only the male has reported earnings in that year, and the remaining 22\% to 33\% is roughly split between couples in which only the female has reported earnings, and those in which neither has reported earnings, which dominates slightly in three of the four tabulations.

The frequency with dual-earner couples work for the same or similar employers is shown in Table 8. Of Census 2000 respondents working in the year 2000, roughly $10 \%$ to $12 \%$ of two income households work at the same establishment. At broader levels of an employer's definition, this percentage naturally increases, and at its broadest level, that of the firm, $11 \%$ to $13 \%$ of employers share an employer. Industry sharing is rather more common: $13 \%$ to $15 \%$ share the same narrow 6-digit NAICS industry, and 25\% to 26\% share the same broad industry, 
defined at the NAICS supersector level. The industry breakdowns for those that share industry are similar as those tabulated on the Census 2000 alone. At the finer levels of geography, results are similar to Census 2000 responses: $11 \%$ to $13 \%$ of administrative records indicate a shared block of employment (compared to about $10 \%$ to $11 \%$ in the Census 2000 responses), and $14 \%$ to $17 \%$ a shared tract of employment (compared to a $14 \%$ to $17 \%$ range from Census 2000 responses). After that, far lower agreement is found for the broader categories: $50 \%$ work in the same county, and $66 \%$ work within 25 miles of each other, according to the administrative records. This may reflect some differences between the addresses reported for employment reporting versus the locations where the economic activity occurs.

There are few reference points to which to compare the result on shared employers, and readers should note that these comparisons are, at best, rough. The estimate that $11 \%$ to $13 \%$ of couples share an employer is remarkably close to the estimate in Batt and Valcour (2003) that $15 \%$ of the couples in their sample share an employer, but this similarity is most likely coincidental. Batt and Valcour (2003) use the 1998 Cornell Couples and Careers Study which they repeatedly stress is a nonrandom sample of the U.S. population. The authors (on page 199) describe that the Study surveyed exempt (or salaried) employees from several employers in upstate New York: two in manufacturing, two in health care employers, two universities, and one utility company. Moen and Sweet $(2002,2004)$ have different estimates, but are largely from the same data source. They utilize the survey responses from that the same Cornell Couples and Careers Study along with respondents from additional employers, also in upstate New York, to get their estimate that $40 \%$ of dual-earner couples co-work at two manufacturing and three utility employers, and $17 \%$ co-work at two universities. 
The administrative records source provides an opportunity to account for the frequency with which observed Census responses are due to shared workplaces. This is done by computing the frequency of Census 2000 reported of shared or similar industry, occupation, and geography with which couples who work at a shared workplace relative to all couples. Results are shown in Table 9, and are limited to the 38 states for which LEHD data is available for the year 2000, and also exclude those observations with missing sub-county geography. 86.6\% of Census 2000 respondents who are dual-earner in the LEHD data and report having the same industry, occupation, and block share a workplace in the administrative records source. $80.8 \%$ of those who share the same Census block of employment share a workplace. Those who share narrowlydefined Census industry and occupation categories have rather less of their agreement associated with sharing a workplace: $61.0 \%$ and 45\%, respectively. At broader categories, shared workplaces naturally account for less of the Census 2000 agreement.

The frequency with which dual-earner couples share particular industries is shown in Table 10. The three most frequent sectors for couples who share a workplace, Educational Services sector, the Manufacturing sector, and the Health Care and Social Assistance sector, together account for more than half of all couples who share a workplace. Of these, establishment-sharing couples are disproportionate among those who work in Educational Services: nearly half of all males in the Educational Services sector who are in a dual-earner couple with a female partner have a female partner at their same workplace. Industries that also have a disproportionately high frequency of couples sharing a workplace are Utilities, and 
Construction, and Transportation and Warehousing where about 18\%, 24\%, and 19\% of dualearner females are part of a couple with a male at their same workplace, respectively.

The demographic characteristics of those couples who share a workplace are not very different from the population of dual-earner couples, and are shown in Table 11. Members of couples who share a workplace are somewhat older, and more frequently have a Bachelor's Degree, and are more frequently Asian and less frequently Black, than members of the average dual-earner couple. Also included are tabulations of the demographic characteristics of those who do not share an establishment, but share the same firm, six-digit NAICS code, or share the same block of employment. Those who do not share the same workplace but work for the same firm have more education and are more frequently Hispanic than the average dual-earner household. Those who work in the same narrowly-defined NAICS industry, but not the same workplace, are far more likely to have a Bachelor's degree than the average member of a dualearner household. Those who do not share an establishment but share the same block have demographic characteristics that are very similar to those who share a workplace, although they are somewhat younger.

Table 12 contains the frequency with which members of dual-earner share similar LEHD administrative records-based employment characteristics with randomly matched nearby residents. Similar to the Census 2000 results presented in Table 6, shared narrow employment characteristics are about an order of magnitude lower in the randomly matched data compared with the employment characteristics of the real (the "Truth" column) couples, without specifically selecting couples with similar demographic characteristics. Selecting couples with 
similar demographic characteristics doubles the likelihood of sharing the same employer, and also increases the likelihood of sharing other narrowly defined characteristics.

\section{The Dynamics of Spouses as Co-Workers and Co-Residents}

In this section, longitudinal data is used to assess the extent to which the phenomenon of couples sharing an employer is associated with couples forming among co-workers. Specifically, administrative records on household membership and employment for the year 1999 and 2001 is used to subdivide Census 2000 couples who are co-workers and co-residents in 2000 into those in which, in 1999 and 2001, are or are not co-workers or co-residents. These data allow for a basic distinction between the causes described in different studies for why spouses might work for the same employer. For example, if a couple is not co-resident in 1999, but is in 2000, and if, furthermore, the two were co-workers in both 1999 and 2000, then this evidence suggests that these co-workers are newly co-resident, i.e., those co-workers formed a household together. If couples became co-workers between 1999 and 2000, having previously been co-residents, this indicates that a previously existing couple adopted the same employer.

Longitudinal data permits an understanding of the dynamics of spouses as co-workers and co-residents that is necessarily somewhat cruder than the above estimates described above. As before, administrative records on employment are only available for thirty-eight states. Defining employment at the firm-level allows me to avoid difficulties related to establishment imputation. Additionally, less than 95\% of Census 2000 long form records can be linked to 
administrative records sources at all, and only on the order of $70 \%$ have reliable residency data. Residency data comes from the Composite Person Record, see Farber and Leggieri (2002).

This tabulation is presented in Table 13. 51.8\% of couples that are co-worker and coresident in the year 2000 are also co-working and co-resident in the years 1999 and 2001. Of the remainder, the overwhelming majority is co-resident in one or both years. Specifically, this exercise indicates that only $1.8 \%$ of spouses who share an employer in the year 2000 do so because of co-workers in 1999 formed couples. Roughly ten times as many couples, 18.1\%, worked for the same employer having previously been a couple. This suggests that the dominant reason for the phenomenon of spouses working for the same employer is that previously existing couples adopt the same employer. Furthermore, 12.6\% of couples are co-resident in 2001 but not co-working, while $0.7 \%$ are co-working but not co-resident, suggesting that it is even more likely for co-working couples to maintain their relationship when they change employers than is suggested to the respective components of the inflow to co-working couples. In summary, the ten times as many couples, or more, move into and from an employer, relative to newly forming couples on the job, or co-working couples splitting up but continuing to share an employer.

It is possible to transform estimates from Svarer (2007) and Kalmijn and Flap (2001) in order to assess whether the estimates that are presented for the United States is broadly consistent with the evidence they present for Denmark and the Netherlands, respectively. Svarer (2007) considers a dataset that includes 15,000 partnership formations in Denmark and reports that $5 \%$ of couples form with those at the same workplace, and $7 \%$ at the same firm, also providing reasons who these estimates are likely lower bounds. Using data for the Netherlands, 
Kalmijn and Flap (2001) report that for $8 \%$ of such partnerships (at a point in time) the members worked for the same employer prior to the formation of the partnership. The rate of inflow into co-working couples is about $2.7 \%$ of all co-working dual-earner couples, or on the order of $0.3 \%$ of all co-working couples, or $0.15 \%$ of all potential partners. A number of plausible outflow rates would produce a steady-state of couples who met at work that is on the order of $5-8 \%$, although the implied relationship outflow rate of only $1 \%$ is in itself consistent with $13 \%$ of couples expressing that they previously met at work. These transition rates are broadly consistent with a sizable minority of the fraction reporting that they met at work.

\section{Conclusion}

This paper the first systematic analysis of the extent to which couples maintain similar employment or work for the same employer. Acknowledging that the frequencies are somewhat sensitive to definitions, data source, and methodology, we can infer with confidence that, in the United States in the year 2000, about 13\% worked in the same (SOC Major Group) occupation, $21 \%$ to $26 \%$ in the same (NAICS Supersector) industry, and $50 \%$ to $70 \%$ in the same county. This paper is also the first to attempt to systematically document the frequency with which dualearner couples share an employer, and we find the rate to be in the range of $11 \%$ to $13 \%$. These shared employers account for most of the narrowly-defined shared industry, occupation, and location responses to the Census 2000. The phenomenon of couples sharing an employer is mostly accounted for by previously formed couples sharing an employer rather than couples forming at work. 
These estimates provide a starting point for consideration of shared sources of labor income risk. The question of the frequency with which spouses work at the same workplace has substantial implications for family welfare. Those who work at the same workplace may be able to share a commute and spend more time with a spouse. On the other hand, marriage function as consumption insurance: for example, when one member of a couple loses their job, the other member can provide income that lessens its impact. Spouses who work at the same workplace may experience similar demand shocks, which can cause them to experience wage depression or layoffs at similar times. Indeed, Shore $(2010,2013)$ and Ostrovsky (2012) find that couples incomes often move together. The fact that couples frequently share an employer likely explains a substantial portion this positively correlated volatility. Relatedly, the similarity of employment characteristics is a form of assoratative mating that can exacerbate income inequality. ${ }^{9}$

These results also show that employer anti-nepotism policies do not completely eliminate the phenomenon of co-working couples. Wolkenbreit (1997) argues that some employers may fail to adopt anti-nepotism policies out of a concern for profit maximization. The fact that $11 \%$ to $13 \%$ of couples share an employer will be a useful fact for evaluating the population that is likely to be affected by any laws or regulations affecting employer anti-nepotism policies. It also provides evidence that familial social networks are an important source for new employees, which complements recent evidence on intergenerational transmission of employers in Corak and Piraino (2011), Wang (2013), Karmarz and Skans (2014), and Stinson and Wignall (2014).

\footnotetext{
${ }^{9}$ Assotatative mating as relates to household-level income inequality is most often thought of with respect to education. For a recent treatment of this issue, see Greenwood et al. (2014).
} 
It is noteworthy that the order of magnitude of the frequency with which couples work at similar workplaces in the Census 2000 at the finest level of disaggregation is similar to that of shared workplaces in the linked employer-household data. Although there is dissimilarity between the extent of workplace similarity in survey and administrative data, a substantial portion of those who work at similar workplaces in the administrative data report shared workplace characteristics. Current survey designed in such surveys as the Current Population Survey, the American Community Survey, the Survey of Income and Program Participation, the Panel Study of Income Dynamics, the National Longitudinal Survey of Youth, etc. do not ask about whether another member of the household works at the same workplace. It may be possible to increase the accuracy of surveys by, when asking about a respondent's employer, asking whether anyone else in the household works at that same employer. 


\section{References}

Abowd, John M., Bryce E. Stephens, Lars Vilhuber, Fredrik Andersson, Kevin L. McKinney, Marc Roemer, and Simon Woodcock. 2009. "The LEHD Infrastructure Files and the Creation of the Quarterly Workforce Indicators” in Producer Dynamics: New Evidence from Micro Data (Timothy Dunne, J. Bradford Jensen and Mark Roberts, ed.), Chicago: University of Chicago Press, 150-230.

Attanasio, Orazio, Hamish Low and Virginia Sanchez-Marcos. 2008. "Explaining Changes in Female Labor Supply in a Life-Cycle Model” American Economic Review 98(4): 1517-1552.

Batt, Rosemary, and Monique Valcour. 2003. "Human resource practices as predictors of workfamily outcomes and employee turnover”, Industrial Relations, 42(2), 189-220.

Bayer, Patrick, Stephen Ross, and Giorgio Topa. 2008. "Place of Work and Place of Residence: Informal Hiring Networks and Labor Market Outcomes.” Journal of Political Economy 116(6): 1150-96.

Corak, Miles, and Patzirio Piraino. 2011. “The Intergenerational Transmission of Employers.” Journal of Labor Economics 29(1): 37-68. 
Farber, James, and Charlene Leggieri. 2002. "Building and Validating a National Administrative Records Database for the United States”, Paper presented at the New Zealand Conference on Database Integration.

Greenwood, Jeremy, Nezih Guner, Georgi Kocharkov, and Cezar Santos. 2014. "Marry Your Like: Assortative Mating and Income Inequality.” American Economic Review: Papers \& Proceedings 2014 104(5): 348-353.

Haltiwanger, John C., Henry R. Hyatt, Erika McEntarfer, Liliana Sousa, and Stephen R. Tibbets. 2014. "Firm Age And Size In The Longitudinal Employer-Household Dynamics Data” Center for Economic Studies Discussion Paper CES-14-16.

Hess, Gregory. 2004. "Marriage and Consumption Insurance: What's Love Got to Do with It?” Journal of Political Economy 112(2): 290-318.

Hellerstein, Judith, Mark Kutzbach, and David Neumark. 2013. "Do Labor Markets Have an Important Spatial Dimension?” Journal of Urban Economics 79(C): 39-58.

Hyslop, Dean. 2001. "Rising U.S. Earnings Inequality and Family Labor Supply: The Covariance Structure of Intrafamily Earnings” American Economic Review 91(4): pp. 755-777.

Jarmin, Ronald and Javier Miranda. 2002. “The Longitudinal Business Database.” U.S. Census Bureau: Center for Economic Studies Working Paper 02-17. 
Kalmijn, Matthijs, and Henk Flap. 2001. “Assortative Meeting and Mating: Unintended Consequences of Organized Settings for Partner Choices.” Social Forces 79(4): pp 1289-1312.

Kramarz, Francis, and Oskar Skans. 2014. "When Strong Ties are Strong: Networks and Youth Labor Market Entry.” Review of Economic Studies 81(3): 1164-1200.

Lundberg, Shelly. “The Added Worker Effect”, Journal of Labor Economics, Vol. 3, No. 1, Part 1 (Jan., 1985), pp. 11-37.

McKinney, Kevin and Lars Vilhuber. 2011. "LEHD Infrastructure Files in the Census RDC: Overview of s2004 Snapshot.” U.S. Census Bureau Center for Economic Studies Discussion Paper No. CES-WP-11-13.

McKinnish, Terra. 2007. "Sexually-Integrated Workplaces and Divorce: Another Form of Onthe-Job Search” Journal of Human Resources, 42(2), 331-352.

Moen, Phyllis and Stephen Sweet. 2002. “Two Careers, One Employer: Couples Working for the Same Corporation,” Journal of Vocational Behavior, 61, 466-483.

Moen, Phyllis and Stephen Sweet. 2004. “Co-working as a Career Strategy: Implications for the Work and Family Lives of University Employees,” Innovative Higher Education, 28(4), 255272. 
Ostrovsky, Yuri. 2012. “The Correlation of Spouses’ Permanent and Transitory Earnings and Family Income Inequality in Canada.” Labour Economics 19(5): 756-758.

Schmutte, Ian. 2015. “Job Referral Networks and the Determination of Earnings in Local Labor Markets.” Journal of Labor Economics 33(1): 1-32.

Shore, Stephen. 2010. "For Better, for Worse: Intrahousehold Risk-Sharing Over the Business Cycle,” Review of Economics and Statistics, 92(3): 536-548.

Shore, Stephen. 2013. “The Co-Movement of Couples' Incomes,” Review of Economics of the Household, doi: 10.1007/s11150-013-9204-y.

Shore, Stephen and Todd Sinai. 2010. “Commitment, Risk, and Consumption: Do Birds of a Feather Have Bigger Nests?” Review of Economics and Statistics, 92(2): pp. 408-424.

Stinson, Martha, and Christopher Wignall. 2014. "Fathers, Children, and the Intergenerational Transmission of Employers.” U.S. Census Bureau Survey of Income and Program Participation Working Paper No. 265.

Svarer, Michael. 2007. “Working Late: Do Workplace Sex Ratios Affect Partnership Formation and Dissolution?” The Journal of Human Resources 42(3), pp. 583-595. 
U.S. Census Bureau. 2001a. “Industry Code Crosswalk: 1990 Census, 1997 NAICS, and Census 2000”. Dated January 1, 2001 and last accessed in on November 3, 2011 at http://www.census.gov/hhes/www/ioindex/indcswk2k.pdf.

U.S. Census Bureau. 2001b. “Census 2000 Occupational Categories, With Standard Occupational Classification (SOC) Equivalents”,. Dated January 1, 2001 and last accessed in on November 3, 2011 at http://www.census.gov/hhes/www/ioindex/occ2000t.pdf.

Wang, Shing-Yi. 2013. "Marriage Networks, Nepotism, and Labor Market Outcomes in China.” American Economic Journal: Applied Economics 5(3): 91-112.

Wolkenbreit, Randi. 1997. "In Order to Form a More Perfect Union: Applying No-Spouse Rules to Employees Who Meet at Work.” Columbia Journal of Law and Social Problems 31(1): 119166.

Zhang, Sisi. 2011. "Wage Shocks, Household Labor Supply, and Income Instability.” Unpublished draft, University of British Columbia. 
Table 1: Household employment status

\begin{tabular}{lccc}
\hline \hline Household employment status & $\begin{array}{c}\text { All } \\
\text { Couples }\end{array}$ & $\begin{array}{c}\text { Married } \\
\text { Partner }\end{array}$ \\
\hline Both male and female with a job, at work & 57.7 & 57.5 & 60.1 \\
Male only with a job, at work & 25.8 & 26.4 & 19.6 \\
Female only with a job, at work & 7.6 & 7.3 & 10.4 \\
Neither partner with a job, at work & 8.9 & 8.8 & 9.9 \\
$\mathrm{~N}$ (weighted, in millions) & 49.7 & 45.3 & 4.4 \\
\hline Notes: Household-level calculations for a the public-use Census 2000 long form responses of \\
married and unmarried partner households who reside in the 50 states or the District of \\
Columbia in which both members of the couple are age 16-64 and do not live in Group \\
Quarters. Responses are weighted by the person weight of the primary respondent.
\end{tabular}


Table 2: Similar employment for couples in which both members work (percent)

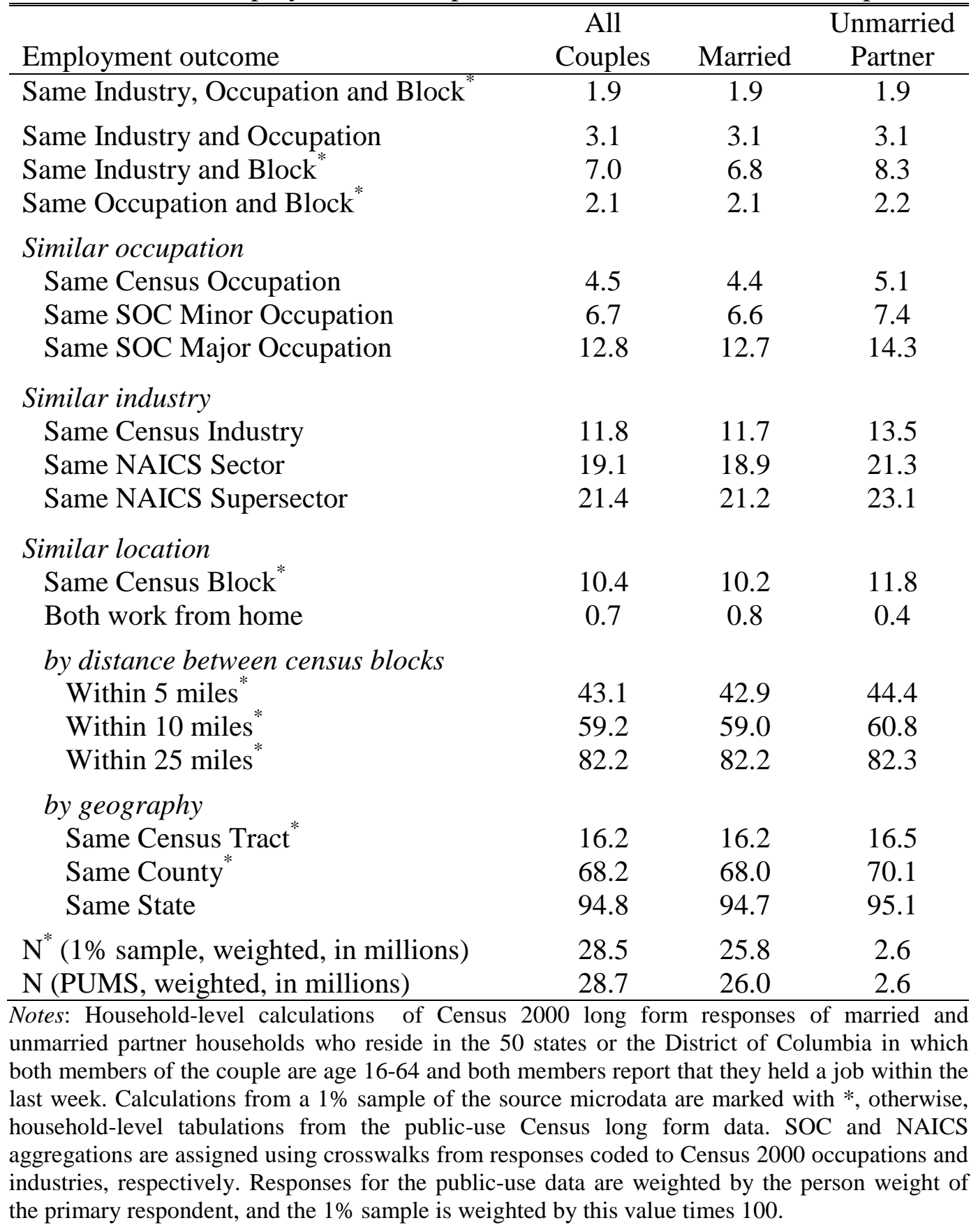


Table 3: Occupations of men, women, and shared occupations for couples in which both members work in the Census 2000

\begin{tabular}{|c|c|c|c|c|}
\hline SOC Major Group & $\begin{array}{l}\text { All } \\
\text { Males }\end{array}$ & $\begin{array}{c}\text { All } \\
\text { Females }\end{array}$ & $\begin{array}{c}\text { Same } \\
\text { Census } \\
\text { Occupation }\end{array}$ & $\begin{array}{l}\text { Same } \\
\text { SOC Major } \\
\text { Group }\end{array}$ \\
\hline Management & 13.3 & 8.1 & 13.3 & 14.7 \\
\hline Business and Financial Operations & 4.3 & 5.7 & 4.3 & 3.8 \\
\hline Computer and Mathematical & 3.3 & 1.8 & 3.1 & 2.5 \\
\hline Architecture and Engineering & 3.9 & 0.6 & 1.4 & 1.1 \\
\hline Life, Physical, and Social Science & 1.2 & 0.9 & 1.5 & 0.9 \\
\hline Community and Social Services & 1.3 & 1.9 & 1.6 & 1.1 \\
\hline Legal & 1.2 & 1.2 & 3.3 & 1.5 \\
\hline Education, Training and Library & 3.3 & 10.8 & 14.0 & 9.5 \\
\hline $\begin{array}{l}\text { Arts, Design, Entertainment, Sports } \\
\text { and Media }\end{array}$ & 1.8 & 2.0 & 2.1 & 1.7 \\
\hline $\begin{array}{l}\text { Healthcare Practitioners and } \\
\text { Technical }\end{array}$ & 2.5 & 8.7 & 8.4 & 6.8 \\
\hline Healthcare Support & 0.3 & 3.2 & 1.1 & 0.4 \\
\hline Protective Service & 3.4 & 0.6 & 2.0 & 1.3 \\
\hline $\begin{array}{l}\text { Food Preparation and Serving } \\
\text { Related }\end{array}$ & 1.6 & 3.9 & 3.0 & 2.9 \\
\hline $\begin{array}{l}\text { Building and Grounds Cleaning and } \\
\text { Maintenance }\end{array}$ & 2.9 & 2.2 & 3.5 & 2.4 \\
\hline Personal Care and Service & 0.8 & 4.4 & 1.9 & 1.1 \\
\hline Sales and Related & 10.5 & 10.1 & 14.9 & 14.3 \\
\hline Office and Administrative Support & 6.2 & 25.7 & 5.4 & 15.8 \\
\hline Farming, Fishing, and Forestry & 0.7 & 0.3 & 1.4 & 0.6 \\
\hline Construction and Extraction & 9.5 & 0.3 & 1.3 & 0.9 \\
\hline $\begin{array}{l}\text { Installation, Maintenance, and } \\
\text { Repair }\end{array}$ & 7.8 & 0.4 & 0.8 & 0.6 \\
\hline Production & 11.0 & 5.4 & 7.6 & 12.7 \\
\hline Transportation and Material Moving & 8.6 & 1.8 & 3.9 & 3.2 \\
\hline Military Specific & 0.3 & 0.0 & 0.2 & 0.1 \\
\hline $\mathrm{N}$ (weighted, in millions) & 28.7 & 28.7 & 1.3 & 3.7 \\
\hline
\end{tabular}


Table 4: Industry of men, women, and shared occupations for couples in which both members work in the Census 2000

\begin{tabular}{|c|c|c|c|c|}
\hline NAICS Sector & $\begin{array}{c}\text { All } \\
\text { Males }\end{array}$ & $\begin{array}{c}\text { All } \\
\text { Females }\end{array}$ & $\begin{array}{c}\text { Same } \\
\text { Census } \\
\text { Industry }\end{array}$ & $\begin{array}{l}\text { Same } \\
\text { NAICS } \\
\text { Sector }\end{array}$ \\
\hline $\begin{array}{l}\text { Agriculture, Forestry, Fishing and } \\
\text { Hunting }\end{array}$ & 2 & 0.7 & 2.4 & 1.8 \\
\hline $\begin{array}{l}\text { Mining, Quarrying, and Oil and } \\
\text { Gas Extraction }\end{array}$ & 0.6 & 0.1 & 0.2 & 0.2 \\
\hline Utilities & 1.7 & 0.5 & 0.5 & 0.4 \\
\hline Construction & 11.2 & 1.7 & 6.5 & 4 \\
\hline Manufacturing & 19.8 & 9.8 & 14 & 21.7 \\
\hline Wholesale Trade & 5.1 & 2.5 & 2.4 & 2.4 \\
\hline Retail Trade & 9.3 & 10.8 & 9.2 & 11.3 \\
\hline Transportation and Warehousing & 6.3 & 2.4 & 3.8 & 3.3 \\
\hline Information & 3.1 & 2.8 & 2.3 & 2.2 \\
\hline Finance and Insurance & 3.9 & 7.3 & 4.5 & 4.2 \\
\hline Real Estate and Rental and Leasing & 1.7 & 1.9 & 2.1 & 1.3 \\
\hline $\begin{array}{l}\text { Professional, Scientific, and } \\
\text { Technical Services }\end{array}$ & 6.3 & 6.2 & 6 & 6.5 \\
\hline $\begin{array}{l}\text { Management of Companies and } \\
\text { Enterprises }\end{array}$ & 0.1 & 0.1 & 0 & 0 \\
\hline $\begin{array}{l}\text { Administrative and Support and } \\
\text { Waste Management and } \\
\text { Remediation Services }\end{array}$ & 2.9 & 2.8 & 2.4 & 1.9 \\
\hline Educational Services & 5.6 & 15.1 & 16.5 & 12.7 \\
\hline Health Care and Social Assistance & 4.5 & 19.6 & 9.2 & 10.7 \\
\hline Arts, Entertainment, and Recreation & 1.4 & 1.4 & 1.7 & 1.1 \\
\hline Accommodation and Food Services & 2.9 & 4.6 & 7.1 & 4.9 \\
\hline Other Services (excl. Publ. Admin.) & 4.4 & 4.9 & 3.8 & 3.4 \\
\hline Public Administration & 7.3 & 4.8 & 5.4 & 6.1 \\
\hline N (weighted, in millions) & 28.7 & 28.7 & 3.4 & 5.5 \\
\hline
\end{tabular}


Table 5: Characteristics of Dual-Earner Couples, by Similar Employment

\begin{tabular}{|c|c|c|c|c|}
\hline Characteristics & $\begin{array}{l}\text { All Dual- } \\
\text { Earner } \\
\text { Couples }\end{array}$ & $\begin{array}{c}\text { Shared } \\
\text { Census } \\
\text { Occupation }\end{array}$ & $\begin{array}{l}\text { Shared } \\
\text { Census } \\
\text { Industry }\end{array}$ & $\begin{array}{l}\text { Shared } \\
\text { Census } \\
\text { Block }^{*}\end{array}$ \\
\hline \multicolumn{5}{|l|}{ Male } \\
\hline \multicolumn{5}{|l|}{ Age } \\
\hline 16 to 24 & 3.6 & 3.6 & 3.4 & 3.2 \\
\hline 25 to 44 & 54.6 & 52.6 & 50.4 & 53.6 \\
\hline 45 to 54 & 29.3 & 29.4 & 31 & 28.7 \\
\hline 55 to 64 & 12.6 & 14.3 & 15.3 & 14.5 \\
\hline \multicolumn{5}{|l|}{ Race \& Ethnicity } \\
\hline White & 83.6 & 79.9 & 82.8 & 80.2 \\
\hline Black & 7.6 & 5.8 & 5.8 & 5.3 \\
\hline Asian & 3.2 & 7.7 & 5.6 & 8.9 \\
\hline Hispanic of any race & 7.7 & 9.3 & 8.3 & 9.0 \\
\hline \multicolumn{5}{|l|}{ Education } \\
\hline Less than High School & 9.9 & 10.2 & 9.7 & 9.9 \\
\hline High School Diploma & 26.6 & 17.7 & 21.9 & 17.5 \\
\hline Some College or Assoc. Deg. & 31.6 & 22.9 & 27.4 & 22.0 \\
\hline Bachelor’s Degree or more & 31.8 & 49.2 & 41.1 & 50.7 \\
\hline \multicolumn{5}{|l|}{ Female } \\
\hline \multicolumn{5}{|l|}{ Age } \\
\hline 16 to 24 & 5.8 & 5.7 & 5.5 & 5.2 \\
\hline 25 to 44 & 59.5 & 58.8 & 56.6 & 59.3 \\
\hline 45 to 54 & 27 & 27.1 & 28.7 & 27.6 \\
\hline 55 to 64 & 7.6 & 8.4 & 9.2 & 7.9 \\
\hline \multicolumn{5}{|l|}{ Race \& Ethnicity } \\
\hline White & 83.6 & 79.4 & 82.6 & 80.0 \\
\hline Black & 6.9 & 5.2 & 5.2 & 5.3 \\
\hline Asian & 3.8 & 8.6 & 6.2 & 9.4 \\
\hline Hispanic of any race & 7.8 & 9.5 & 8.5 & 9.6 \\
\hline \multicolumn{5}{|l|}{ Education } \\
\hline Less than High School & 7.4 & 9.8 & 8.4 & 9.8 \\
\hline High School Diploma & 26.4 & 20.1 & 24.4 & 20.6 \\
\hline Some College or Assoc. Deg. & 34.7 & 23.8 & 31.2 & 22.8 \\
\hline Bachelor’s Degree or more & 31.5 & 46.3 & 36.0 & 46.9 \\
\hline N (weighted, in millions) & 28.7 & 1.3 & 3.4 & 1.3 \\
\hline \multicolumn{5}{|c|}{$\begin{array}{l}\text { Notes: Household-level calculations of Census } 2000 \text { long form responses of married and unmarried partner } \\
\text { households who reside in the } 50 \text { states or the District of Columbia in which both members of the couple are } \\
\text { age } 16-64 \text { and both members report that they held a job within the last week. Calculations from a } 1 \% \text { sample } \\
\text { of the source microdata are marked with } * \text {, otherwise, household-level tabulations from the public-use } \\
\text { Census long form data. Responses for the public-use data are weighted by the person weight of the primary } \\
\text { respondent, and the } 1 \% \text { sample is weighted by this value times } 100 \text {. }\end{array}$} \\
\hline
\end{tabular}


Table 6: Random Assignment Comparison within Census Block, Census 2000 Alone

\begin{tabular}{|c|c|c|c|c|}
\hline \multirow[b]{2}{*}{ Employment outcome } & \multicolumn{2}{|c|}{$\begin{array}{l}\text { Any other couple } \\
\text { within block }\end{array}$} & \multicolumn{2}{|c|}{$\begin{array}{c}\text { Match within block, with } \\
\text { similar demographic } \\
\text { characteristics }\end{array}$} \\
\hline & Truth & Random & Truth & Random \\
\hline Same Industry, Occupation and Block & 2.3 & 0.1 & 2.0 & 0.1 \\
\hline Same Industry and Occupation & 3.9 & 0.4 & 3.9 & 0.8 \\
\hline Same Industry and Block & 8.5 & 0.4 & 8.4 & 0.8 \\
\hline Same Occupation and Block & 2.6 & 0.1 & 2.6 & 0.1 \\
\hline \multicolumn{5}{|l|}{ Similar occupation } \\
\hline Same Census Occupation & 5.7 & 1.0 & 6.5 & 1.5 \\
\hline Same SOC Minor Occupation & 8.1 & 2.4 & 9.1 & 3.1 \\
\hline Same SOC Major Occupation & 14.6 & 7.3 & 15.2 & 8.6 \\
\hline \multicolumn{5}{|l|}{ Similar industry } \\
\hline Same Census Industry & 14.4 & 2.6 & 14.9 & 3.7 \\
\hline Same NAICS Sector & 21.9 & 9.3 & 23.9 & 11.5 \\
\hline Same NAICS Supersector & 24.3 & 12.0 & 25.6 & 14.7 \\
\hline \multicolumn{5}{|l|}{ Similar location } \\
\hline Same Census Block & 10.8 & 0.8 & 10.8 & 1.2 \\
\hline \multicolumn{5}{|l|}{ by distance between blocks } \\
\hline Within 5 miles & 42.5 & 30.5 & 44.9 & 32.6 \\
\hline Within 10 miles & 64.5 & 54.5 & 67.1 & 59.3 \\
\hline Within 25 miles & 91.2 & 85.3 & 91.6 & 89.9 \\
\hline \multicolumn{5}{|l|}{ by geography } \\
\hline Same Census Tract & 14.8 & 3.8 & 14.9 & 4.9 \\
\hline Same County & 69.8 & 60.1 & 70.9 & 64.0 \\
\hline Same State & 95.3 & 90.5 & 96.3 & 94.3 \\
\hline $\mathrm{N}$ (weighted, in millions) & 9.8 & 9.8 & 2.1 & 2.1 \\
\hline
\end{tabular}

Notes: Household-level calculations for a 1\% sample of Census 2000 long form responses of married and unmarried partner households in which both members of the couple are age 16-64 and both members report that they held a job within the last week. SOC and NAICS aggregations are assigned using crosswalks from responses coded to Census 2000 occupations and industries, respectively. Responses are weighted by the person weight of the primary respondent times 100 . 


\begin{tabular}{|c|c|c|c|c|}
\hline \multirow[b]{2}{*}{ Household employment status } & \multicolumn{2}{|c|}{ All Couples } & \multicolumn{2}{|c|}{$\begin{array}{c}\text { Excluding Households } \\
\text { with Feds, Self-Employed }\end{array}$} \\
\hline & 38 States & National & 38 States & National \\
\hline Both male and female in LEHD & 43.2 & 39.7 & 51.4 & 46.7 \\
\hline Male only in LEHD & 24.9 & 26.7 & 25.7 & 27.3 \\
\hline Female only in LEHD & 15.0 & 14.5 & 11.6 & 11.7 \\
\hline Neither partner in LEHD & 16.8 & 19.0 & 11.2 & 14.3 \\
\hline N (weighted, in millions) & 38.5 & 49.3 & 29.7 & 38.0 \\
\hline \multicolumn{5}{|c|}{$\begin{array}{l}\text { Notes: Household-level calculations for a } 1 \% \text { sample Census } 2000 \text { long form responses of married and unmarried } \\
\text { partner households who reside in the } 50 \text { states or the District of Columbia in which both members of the couple are } \\
\text { age } 16-64 \text {. LEHD data is only available for } 38 \text { states in the year } 2000 \text {. The "38 States" estimates reflect the } \\
\text { households that lives in those } 38 \text { LEHD states in the Census } 2000 \text {, using only direct tabulation of the LEHD data, } \\
\text { and both members were assigned a PIK. The "National" include all households, and impute employment responses } \\
\text { for all missing states, and impute outcomes for households where one or both PIKs are missing. Observations are } \\
\text { weighted by the person weight of the primary respondent times } 100 \text {. }\end{array}$} \\
\hline
\end{tabular}


Table 8: Same and Similar Workplaces among Dual-Earner Couples in 2000, LEHD Data

\begin{tabular}{|c|c|c|c|c|}
\hline \multirow[b]{2}{*}{ Employment outcome } & \multicolumn{2}{|c|}{ All Couples } & \multicolumn{2}{|c|}{$\begin{array}{l}\text { Excluding Census } 2000 \\
\text { Feds, Self-Employed }\end{array}$} \\
\hline & 38 States & National & 38 States & National \\
\hline \multicolumn{5}{|l|}{ Shared Employer } \\
\hline Same Workplace & 11.7 & 11.7 & 10.3 & 10.3 \\
\hline Same SEIN & 12.7 & 12.5 & 11.3 & 11.2 \\
\hline Same (F)EIN & 12.9 & 12.8 & 11.5 & 11.5 \\
\hline Same Firm & 13.1 & 13.0 & 11.7 & 11.7 \\
\hline \multicolumn{5}{|l|}{ Shared Industry } \\
\hline Same 6-Digit NAICS & 14.8 & 15.0 & 13.4 & 13.7 \\
\hline Same Group & 15.3 & 15.6 & 14.0 & 14.4 \\
\hline Same Sector & 23.1 & 22.3 & 22.0 & 21.4 \\
\hline Same Supersector & 25.9 & 26.0 & 24.9 & 25.1 \\
\hline \multicolumn{5}{|l|}{ Shared Geography } \\
\hline Same Block & 12.5 & 13.1 & 11.1 & 11.6 \\
\hline Same Tract & 15.8 & 16.6 & 14.4 & 15.3 \\
\hline Same County & 50.4 & 50.5 & 49.6 & 50.0 \\
\hline Same State & 95.1 & 94.8 & 95.3 & 95.0 \\
\hline Within 5 miles & 31.0 & 34.1 & 29.8 & 32.8 \\
\hline Within 10 miles & 46.7 & 49.1 & 45.7 & 48.2 \\
\hline Within 25 miles & 66.8 & 66.4 & 66.4 & 66.1 \\
\hline $\mathrm{N}$ (weighted, in millions) & 16.6 & 19.6 & 15.3 & 17.8 \\
\hline \multicolumn{5}{|c|}{$\begin{array}{l}\text { Notes: Household-level calculations for a } 1 \% \text { sample Census } 2000 \text { long form responses of married and unmarried } \\
\text { partner households who reside in the } 50 \text { states or the District of Columbia in which both members of the couple are } \\
\text { age } 16-64 \text { and both members report that they held a job within the last week. To be included, both members of the } \\
\text { couple must have an person identification key, and must have an employer in the LEHD data. LEHD data is } \\
\text { available for } 38 \text { states. The " } 38 \text { States" estimates reflect the households that lives in those } 38 \text { LEHD states in the } \\
\text { Census } 2000 \text {, using only direct tabulation of the LEHD data. The "National" include all households, and impute } \\
\text { employment responses for all missing states. Observations are weighted by the person weight of the primary } \\
\text { respondent times } 100 \text {. }\end{array}$} \\
\hline
\end{tabular}


Table 9: Similar employment for couples in which both members work (percent)

\begin{tabular}{lcccc}
\hline \hline & All & $\begin{array}{c}\text { Different } \\
\text { Employment outcome }\end{array}$ & $\begin{array}{c}\text { Shared } \\
\text { Couples }\end{array}$ & $\begin{array}{c}\text { Shared } \\
\text { Workplace as } \\
\text { Percent of All }\end{array}$ \\
\hline Same Industry, Occupation and & 1.4 & 0.3 & 11.5 & 83.8 \\
Block & 2.7 & 1.1 & 17.2 & 64.7 \\
& 6.1 & 1.2 & 48.7 & 82.8 \\
Same Industry and Occupation & 1.6 & 0.4 & 12.6 & 80.1 \\
Same Industry and Block & 1.4 & 0.3 & 11.5 & 83.8 \\
Same Occupation and Block & & & & \\
Similar occupation & 4.2 & 2.5 & 18.9 & 46.6 \\
Same Census Occupation & 6.5 & 4.4 & 24.6 & 38.9 \\
Same SOC Minor Occupation & 13.0 & 10.5 & 34.9 & 27.8 \\
$\quad$ Same SOC Major Occupation & & & & \\
Similar industry & 11.7 & 4.8 & 71.1 & 63.1 \\
$\quad$ Same Census Industry & 19.9 & 13.2 & 77.9 & 40.5 \\
Same NAICS Sector & 22.4 & 15.9 & 78.9 & 36.5 \\
$\quad$ Same NAICS Supersector & & & & \\
Similar location & 8.5 & 2.8 & 57.4 & 70.0 \\
$\quad$ Same Census Block & & & & \\
by distance between blocks & 40.7 & 36.5 & 77.1 & 19.6 \\
$\quad$ Within 5 miles & 57.6 & 54.6 & 84.1 & 15.1 \\
$\quad$ Within 10 miles & 80.7 & 79.5 & 90.9 & 11.7 \\
$\quad$ Within 25 miles & & & & \\
by geography & 14.0 & 8.5 & 61.8 & 45.7 \\
$\quad$ Same Census Tract & 65.4 & 62.6 & 89.3 & 14.1 \\
$\quad$ Same County & 93.2 & 92.9 & 95.7 & 10.6 \\
$\quad$ Same State & 13.8 & 12.4 & 1.4 & \\
N (weighted, in millions) & & & & \\
\hline
\end{tabular}

Notes: Household-level calculations for a 1\% sample Census 2000 long form responses of married and unmarried partner households who reside in the 50 states or the District of Columbia in which both members of the couple are age 16-64 and both members report that they held a job within the last week and neither member has missing subcounty geography, linked with 38 states with LEHD data. SOC and NAICS aggregations are assigned using crosswalks from responses coded to Census 2000 occupations and industries, respectively. Responses are weighted by the person weight of the primary respondent times 100 . 
Table 10: Maximal earning industry of men, women, and shared occupations for couples in which both members work in the Census 2000

\begin{tabular}{|c|c|c|c|c|c|}
\hline NAICS Sector & $\begin{array}{c}\text { All } \\
\text { Males }\end{array}$ & $\begin{array}{c}\text { All } \\
\text { Females }\end{array}$ & $\begin{array}{c}\text { Same } \\
\text { Workplace }\end{array}$ & $\begin{array}{c}\text { Same } \\
\text { NAICS } \\
\text { Industry } \\
\text { (6 Digit) }\end{array}$ & $\begin{array}{l}\text { Same } \\
\text { NAICS } \\
\text { Sector }\end{array}$ \\
\hline $\begin{array}{l}\text { Agriculture, Forestry, Fishing } \\
\text { and Hunting }\end{array}$ & 0.7 & 0.4 & 1.1 & 1.0 & 0.9 \\
\hline $\begin{array}{l}\text { Mining, Quarrying, and Oil and } \\
\text { Gas Extraction }\end{array}$ & 0.7 & 0.2 & 0.4 & 0.4 & 0.3 \\
\hline Utilities & 1.5 & 0.4 & 0.8 & 0.7 & 0.6 \\
\hline Construction & 8.4 & 1.4 & 2.9 & 2.3 & 2.1 \\
\hline Manufacturing & 22.9 & 10.7 & 21.2 & 17.8 & 24.5 \\
\hline Wholesale Trade & 7.0 & 3.3 & 4.4 & 3.7 & 3.5 \\
\hline Retail Trade & 10.2 & 10.6 & 9.3 & 9.2 & 11.2 \\
\hline Transportation and Warehousing & 5.0 & 2.0 & 3.1 & 3.1 & 2.6 \\
\hline Information & 3.1 & 2.8 & 2.6 & 2.9 & 2.3 \\
\hline Finance and Insurance & 3.5 & 7.8 & 2.5 & 3.4 & 3.9 \\
\hline $\begin{array}{l}\text { Real Estate and Rental and } \\
\text { Leasing }\end{array}$ & 1.5 & 1.3 & 1.1 & 0.9 & 0.7 \\
\hline $\begin{array}{l}\text { Professional, Scientific, and } \\
\text { Technical Services }\end{array}$ & 5.7 & 6 & 3.7 & 4.1 & 5.1 \\
\hline $\begin{array}{l}\text { Management of Companies and } \\
\text { Enterprises }\end{array}$ & 1.3 & 1.3 & 0.8 & 0.9 & 0.6 \\
\hline $\begin{array}{l}\text { Administrative and Support and } \\
\text { Waste Management and } \\
\text { Remediation Services }\end{array}$ & 4.2 & 4.3 & 4.0 & 3.5 & 3.1 \\
\hline Educational Services & 7.1 & 15.7 & 18.5 & 21.6 & 16.3 \\
\hline $\begin{array}{l}\text { Health Care and Social } \\
\text { Assistance }\end{array}$ & 4.2 & 18.5 & 8.8 & 9.2 & 9.1 \\
\hline $\begin{array}{l}\text { Arts, Entertainment, and } \\
\text { Recreation }\end{array}$ & 1.0 & 1.1 & 1.5 & 1.3 & 0.9 \\
\hline $\begin{array}{l}\text { Accommodation and Food } \\
\text { Services }\end{array}$ & 3.0 & 4.8 & 5.6 & 6.0 & 4.7 \\
\hline $\begin{array}{l}\text { Other Services (excl. Publ. } \\
\text { Admin.) }\end{array}$ & 2.5 & 3 & 1.8 & 1.9 & 1.5 \\
\hline Public Administration & 6.4 & 4.6 & 5.9 & 5.9 & 6.0 \\
\hline $\mathrm{N}$ (weighted, in millions) & 15.3 & 15.3 & 1.6 & 2.1 & 3.4 \\
\hline
\end{tabular}


Table 11: Characteristics of Dual-Earner Couples, by Shared Primary Employer (38 States)

\begin{tabular}{|c|c|c|c|c|c|}
\hline Characteristics & $\begin{array}{l}\text { All Dual- } \\
\text { Earner } \\
\text { Couples }\end{array}$ & $\begin{array}{c}\text { Shared } \\
\text { Workplace }\end{array}$ & $\begin{array}{c}\text { Shared } \\
\text { Firm }\end{array}$ & $\begin{array}{c}\text { ed Workpl } \\
\text { Shared } \\
\text { NAICS } \\
\text { Industry } \\
\text { (6 Digit) }\end{array}$ & $\begin{array}{l}\text { Shared } \\
\text { Block }\end{array}$ \\
\hline \multicolumn{6}{|l|}{ Male } \\
\hline \multicolumn{6}{|l|}{ Age } \\
\hline 16 to 24 & 3.8 & 4.1 & 4.2 & 2.9 & 3.4 \\
\hline 25 to 44 & 57.8 & 55.4 & 55.7 & 57.0 & 61.0 \\
\hline 45 to 54 & 27.5 & 27.7 & 31.3 & 28.3 & 25.4 \\
\hline 55 to 64 & 10.9 & 12.8 & 8.4 & 12.1 & 10.2 \\
\hline \multicolumn{6}{|l|}{ Race \& Ethnicity } \\
\hline White & 83.2 & 81.8 & 77.6 & 81.3 & 82.2 \\
\hline Black & 8.4 & 7.4 & 11.7 & 8.1 & 8.5 \\
\hline Asian & 3.2 & 5.1 & 2.8 & 5.4 & 1.7 \\
\hline Hispanic of any race & 8.6 & 9.0 & 12.2 & 8.9 & 11.9 \\
\hline \multicolumn{6}{|l|}{ Education } \\
\hline Less than High School & 10.6 & 10.9 & 6.5 & 5.8 & 7.6 \\
\hline High School Diploma & 27.7 & 22.7 & 24.8 & 17.0 & 23.7 \\
\hline Some College or Assoc. Deg. & 31.9 & 30.6 & 28.0 & 21.6 & 30.5 \\
\hline Bachelor's Degree or more & 29.9 & 35.8 & 41.1 & 55.5 & 38.1 \\
\hline \multicolumn{6}{|l|}{ Female } \\
\hline \multicolumn{6}{|l|}{ Age } \\
\hline 16 to 24 & 6.3 & 7.6 & 6.5 & 6.4 & 3.4 \\
\hline 25 to 44 & 61.8 & 60.2 & 64.0 & 60.3 & 65.3 \\
\hline 45 to 54 & 25.3 & 25.3 & 25.2 & 26.4 & 23.7 \\
\hline 55 to 64 & 6.5 & 7.1 & 4.2 & 6.9 & 7.6 \\
\hline \multicolumn{6}{|l|}{ Race \& Ethnicity } \\
\hline White & 83.3 & 82.7 & 77.1 & 80.7 & 79.7 \\
\hline Black & 7.8 & 6.9 & 9.8 & 7.1 & 8.5 \\
\hline Asian & 3.9 & 5.3 & 4.7 & 6.2 & 4.2 \\
\hline Hispanic of any race & 8.7 & 9.1 & 10.7 & 9.8 & 10.2 \\
\hline \multicolumn{6}{|l|}{ Education } \\
\hline Less than High School & 7.8 & 9.6 & 5.6 & 6.2 & 7.6 \\
\hline High School Diploma & 27.1 & 27.3 & 22.9 & 16.2 & 26.3 \\
\hline Some College or Assoc. Deg. & 34.8 & 30.2 & 34.1 & 28.3 & 26.3 \\
\hline Bachelor's Degree or more & 30.3 & 32.8 & 36.9 & 49.1 & 39.8 \\
\hline $\mathrm{N}$ (weighted, in millions) & 15.3 & 1.6 & 0.2 & 0.5 & 0.1 \\
\hline
\end{tabular}

Notes: Household-level calculations for a 1\% sample of Census 2000 long form responses of married and unmarried partner households in which both members of the couple are age 16-64 and both members report that they held a job within the last week. Observations are weighted by the person weight of the primary respondent times 100 . 
Table 12: Random Assignment Comparison within Census Block, LEHD Data

\begin{tabular}{|c|c|c|c|c|}
\hline \multirow[b]{2}{*}{ Employment outcome } & \multicolumn{2}{|c|}{$\begin{array}{l}\text { Any other couple } \\
\text { within block }\end{array}$} & \multicolumn{2}{|c|}{$\begin{array}{c}\text { Match within block, with } \\
\text { similar demographic } \\
\text { characteristics }\end{array}$} \\
\hline & Truth & Random & Truth & Random \\
\hline \multicolumn{5}{|l|}{ Shared Employer } \\
\hline Same Workplace & 9.6 & 0.6 & 8.7 & 1.2 \\
\hline Same SEIN & 10.5 & 1.0 & 9.7 & 1.8 \\
\hline Same (F)EIN & 10.8 & 1.1 & 10.0 & 1.9 \\
\hline Same Firm & 11.1 & 1.1 & 10.1 & 2.1 \\
\hline \multicolumn{5}{|l|}{ Shared Geography } \\
\hline Same Block & 10.3 & 1.0 & 9.6 & 1.6 \\
\hline Same Tract & 13.1 & 3.1 & 13.0 & 4.1 \\
\hline Same County & 49.0 & 39.9 & 48.6 & 40.6 \\
\hline Same State & 95.7 & 91.1 & 95.4 & 94.8 \\
\hline Within 5 miles & 29.6 & 19.2 & 29.6 & 20.3 \\
\hline Within 10 miles & 44.0 & 34.0 & 44.3 & 35.9 \\
\hline Within 25 miles & 66.2 & 58.5 & 66.4 & 61.3 \\
\hline \multicolumn{5}{|l|}{ Shared Industry } \\
\hline Same NAICS Industry (6-Digit) & 12.7 & 1.8 & 12.0 & 2.6 \\
\hline Same Group & 13.4 & 2.2 & 13.0 & 3.1 \\
\hline Same Sector & 21.0 & 9.3 & 19.7 & 10.6 \\
\hline Same Supersector & 23.9 & 12.6 & 22.6 & 13.9 \\
\hline $\mathrm{N}$ (weighted, in millions) & 7.9 & 7.9 & 1.7 & 1.7 \\
\hline
\end{tabular}

Notes: Household-level calculations for a 1\% sample of Census 2000 long form responses of married and unmarried partner households in which both members of the couple are age 16-64 and both members report that they held a job within the last week. SOC and NAICS aggregations are assigned using crosswalks from responses coded to Census 2000 occupations and industries, respectively. Responses are weighted by the person weight of the primary respondent times 100. 


\begin{tabular}{ccccc}
\hline \hline & \multicolumn{4}{c}{ 2001 Status } \\
\cline { 2 - 5 } & $\begin{array}{c}\text { Shared } \\
\text { Residence } \\
\text { and } \\
\text { Employer }\end{array}$ & $\begin{array}{c}\text { Shared } \\
\text { Residence } \\
\text { Only }\end{array}$ & $\begin{array}{c}\text { Shared } \\
\text { Employer } \\
\text { Only }\end{array}$ & $\begin{array}{c}\text { Shared } \\
\text { Neither } \\
\text { Residence nor } \\
\text { Employer }\end{array}$ \\
\hline $\begin{array}{c}\text { Shared Residence and } \\
\text { Employer }\end{array}$ & 51.8 & 12.6 & 0.7 & 0.2 \\
$\begin{array}{c}\text { Shared Residence Only } \\
\text { Shared Employer Only }\end{array}$ & 17.2 & 11.2 & 0.3 & 0.3 \\
Shared Neither Residence nor & 1.8 & 0.9 & 0.1 & 0.0 \\
Employer & 1.3 & 1.4 & 0.1 & 0.1
\end{tabular}

Notes: Household-level calculations for a 1\% sample of Census 2000 long form responses of married and unmarried partner households in which both members of the couple are age 16-64 and both members report that they held a job within the last week. Responses are weighted by the person weight of the primary respondent. Both members of the couple must appear in the Composite Person Record in both 1999 and 2001, and be employed at the same employer in the LEHD in 2000, to be included in the tabulation. Responses are weighted by the person weight of the primary respondent times 100 . 